\title{
Facing financialization: The divergent mutations of agricultural cooperatives in postapartheid South Africa
}

\section{Antoine Ducastel ${ }^{1}$ (D) । Ward Anseeuw ${ }^{2}$}

\author{
${ }^{1}$ CIRAD UMR ART-Dev TA C-113/15, 73 rue \\ Jean-François Breton, 34398, cedex 5 \\ Montpellier, France \\ ${ }^{2}$ CIRAD UMR ART-Dev and International Land \\ Coalition, Via Paolo di Dono 44, Rome, Italy \\ Correspondence \\ Antoine Ducastel, CIRAD UMR ART-Dev, TA \\ C-113/15, 73 rue Jean-François Breton, \\ 34398 Montpellier cedex 5, France. \\ Email: antoine.ducastel@cirad.fr
}

\begin{abstract}
This paper analyses the transformation of the South African (former) grain cooperatives since 1994. These entities played a key role in the institutional architecture of the apartheid regime, ensuring the domination of white commercial farmers over the sector. Within the framework of the deregulation of the economy and the agricultural sector, such entities faced transformations of modern capitalism, especially the growing power of financial actors and markets. Although white commercial farmers still largely retain these inherited structures, these companies are presently being targeted more and more by private takeovers and/or private equity deals. Based on two specific empirical examples of private equity deals affecting South African grain cooperatives, this paper describes this financialization process in practice, in particular by analysing the interaction between financial and agricultural actors and the alliances on the ground that determine its "success." In doing so, it details the different trajectories of these (former) cooperatives, highlighting the resilience, mutation, and extinction of commercial agriculture in South Africa.
\end{abstract}

\section{KEYWORDS}

cooperative, financialization, private equity, South Africa

\section{1 | INTRODUCTION}

Until the first democratic election in 1994, the South African agro-food sector was structured with the aim of guaranteeing the collective power of and control by white commercial farmers. Cooperatives, and more particularly grain cooperatives, were part of this state-controlled, institutional architecture. First, these cooperatives developed agricultural infrastructure (silos, retail shops, etc.). Second, as intermediaries in the single-channel marketing scheme, they ensured marketing and management of the agricultural surplus on behalf of their farmers. And third, in order to

The authors acknowledge the two anonymous reviewers of this article for their comments. 
safeguard production, they also provided affordable agricultural services, including financial services (Bayley, 2000; Vink \& Van Rooyen, 2009).

The 1990s were characterized by the deregulation of the agricultural sector, heralding a mutation leading towards the country's contemporary capitalism. On the one hand, the Marketing of Agricultural Products Act (1996) abolished the Commodities Board system and overhauled the cooperatives' regional monopolies, theoretically opening up participation in the sector (Bayley, 2000). On the other hand, it implemented corrective policies, particularly through redistribution and restitution land reform, as well as through Black Economic Empowerment(BEE) affirmative actions (Anseeuw, Liebenberg, \& Kirsten, 2015).

This being said, almost 20 years later, the South African agro-food sector and its transformation are considered as being static, reproducing the same domination structures inherited from apartheid (Bernstein, 2013). In particular, the former cooperatives are denounced as constituting an obstacle for broader sectoral transformation and empowerment, as they have maintained their strategic positions in the agro-food value chains. The preservation of the economic and political order within the sector does not result from the lack of transformation of its institutions; on the contrary, agricultural institutions did restructure in the wake of the country's deregulation, which exposed its agrofood sector to global capitalistic mutations, in particular financialization (Ducastel \& Anseeuw, 2016). This is well illustrated by the conversion of the former cooperatives into public (private?) companies, some of them becoming listed entities, whereas others adopted shareholding structures.

Generally, the notion of financialization is widely discussed and has been interpreted differently according to various disciplines and fieldworks. ${ }^{1}$ At the microlevel, financialization characterizes the increasing power of financial actors and devices over enterprises and productive activities. At this scale, financialization is associated with the diffusion of shareholder value principles as the dominant governance model (Fligstein \& Shin, 2007). At the macrolevel, on the other hand, financialization is conceptualized as an emerging "regime of accumulation" ${ }^{2}$ (Boyer, 2000; Krippner, 2005). At the macrolevel, the approach has been largely mobilized in agrarian studies, ${ }^{3}$ so several authors have identified a "new food regime" characterized by the expansion of "finance capital" (Ouma, 2014). According to this, agriculture is considered as the last "spatial fix" of capital (Fairbairn, 2014).

Although these approaches link agricultural transformations with those of the broader regime of accumulation, they face several limits. First, the concrete mechanisms making and framing the financialization are missing; second, seen from above, the financialization of agriculture appears as an a-historical, homogeneous, and irreversible process; third, finance and agriculture are "reified," that is, considered as strictly separated and stable fields with the idea that the first one is colonizing the second ${ }^{4}$ (Ducastel \& Anseeuw, 2017). On the contrary, and in order to assess the changing relationships between finance and agriculture, a broader, historically anchored approach, taking into consideration its longer term processes and the actors engaged in them, seems to be necessary.

The objective of this article is thus to analyse the tumultuous and changing relationships between finance and agriculture in South Africa and their impact on the agri-food sector's political economy. Analysing this phenomenon in a historical perspective is a good way to capture and understand the agrarian capitalism mutation and its articulation with the national and global regimes of accumulation. Consequently, financialization appears at a particular juncture,

\footnotetext{
${ }^{1}$ For an overview of "financialization studies" see Van der Zwan (2014), and for a debate on the concept of financialization and its relevance, refer to the special issue by Brett Christophers in Dialogue in Human Geographies, 5(2), 2015.

${ }^{2}$ Boyer defines a "regime of accumulation" as "a set of regularities that ensure the general and relatively coherent progress of capital accumulation, that is, that allow for the resolution of or postponement of the distortions and disequilibria to which the process continually gives rise" (Boyer, 1990: 35).

${ }^{3}$ For a review of major academic works on the financialization of agriculture, see the presentations of two symposiums published by Oane Visser, Jennifer Clapp, and Ryan Isakson in the Journal of Agrarian Change, 15(4), 2015; a special issue published by Jennifer Clapp, Oane Visser, and Ryan Isakson in Agriculture and Human Values, 34(1), 2017; and also several articles in the Journal of Peasant Studies, 41(5), 2014.

${ }^{4}$ As such, Ryan Isakson (2014: 752) states that "it (financialisation) has redistributed wealth and power from agricultural producers and workers to financial elites and exacerbated the fragility of the global industrial food system."
} 
spatially and temporally situated in the (long) history of finance-agriculture relations (Martin \& Clapp, 2015). In addition, it is not a linear and homogeneous process, but rather the local outcome of actors' negotiations and interactions. Rather than a binary opposition between "finance capital" and "agrarian capital," the financialization of the agro-food sector appears as the result of complex interactions between actors from the financial industry (banks, institutional investors, and asset managers), the agricultural sector (farmers, managers of agricultural co-ops) and the state. Such interactions take place in an intermediary space, at the intersection of finance and agriculture but distinct from each, in what Williams (2014) has characterized as the "AG space." ${ }^{5}$ This is analysed elsewhere as "agro-financial filières" (Ducastel \& Anseeuw, 2017).

In order to better understand the complex interactions between actors, and as such grasp the changing relationships between finance and agriculture and the financialization process in South Africa, this paper focuses on the above-mentioned grain cooperatives. Not only are the South African grain cooperatives emblematic of the country's capitalist mutation, but in recent years, they have also been particularly targeted by institutional investors. These are described by Aglietta and Rigot $(2009,179-80)$ as "specialized financial institutions collectively managing third parties' saving schemes according to specific objectives in terms of risk, return and maturity", that is, pension funds or insurance companies, operating through either public takeovers on the stock exchange or private equity transactions. Based on the analysis of the mutations of cooperatives, the paper endeavours to characterize financialization processes at local and sectorial levels. These grain cooperatives are not the only vector of financialization in South Africa's agricultural sector, nor do they represent the most important channel. However, they are interesting case studies to highlight and analyse local conflicts and alliances underlying this pattern of accumulation.

To contextualize the topic, the paper starts by developing a short historical detour along the genealogy of finance-agriculture relations in South Africa since the beginning of the 20th century. It then presents and assesses two cases, starting with the Afgri case. Afgri is a former co-op based in Mpumalanga, listed on the Johannesburg Stock Exchange (JSE) in 1996 and recently taken over by private equity investors. This trajectory could be regarded at first glance as an "ideal type" of corporate financialization, from a farmer-controlled cooperative to a private company held by South African and foreign institutional investors. Thereafter, the paper presents the attempts of an investment holding company, Zeder, to acquire and restructure several unlisted former co-ops. The project has since been abandoned, giving a concrete example of the tensions generated by the confrontation between institutional investors and commercial farmers. Finally, in conclusion, the paper synthesizes the findings from both cases, linking them to the broader transformation of South African and global capitalist systems.

\section{2 | FINANCE AND COMMERCIAL AGRICULTURE IN SOUTH AFRICA}

From the late 19th century, South Africa's agricultural sector was indoctrinated to respond to the country's rapid growth of mining activities. Black farming activities were constrained, enabling the provision of cheap labour to mines (Cochet, 2015), whereas governments progressively supported the emergence of a white commercial agricultural sector provisioning the mines and urban centres with cheap food (Bernstein, 2013).

To do so, the Land Bank was set up in 1912, ${ }^{7}$ granting short- and medium-term loans to white farmers and their cooperatives (Jacobs, 2013). This financial parastatal was positioned under the supervision of the Department of Finance and was accountable to Parliament. Progressively, the Land Bank became instrumental in the development of agriculture, as well as the broader economic structure in South Africa. Besides many other activities, it channelled

\footnotetext{
${ }^{5}$ That is, "the spaces where finance and agriculture commingle as well as the forms of extension and intermediation that allow farms, crops and farmers to be connected to the social and material worlds of finance" (Williams, 2014: 402).

6"Agro-financial filières are stabilized networks including dispersed actors embedded into different fields and territories brought together in order to valorize capital from the agro-food sector" (Ducastel \& Anseeuw, 2017: 261-262).

${ }^{7}$ Before the establishment of the Land Bank, several commercial and provincial banks involved in agricultural activities were in existence, especially around Cape Town, furnishing working capital to the farmers (Jones, Vivian, \& Vink, 2010).
} 
public subsidies to the white commercial farmers and consolidated their debts, especially during the Great Depression in the 1930s (Jacobs, 2013).

Along with the Land Bank, the agricultural cooperatives played an increasing role in the financing of the sector. Officially recognized in 1922 by the Cooperative Societies Act as intermediaries between the Land Bank and the farmers, these co-ops selected and supervised beneficiaries. Later, the Marketing Act (1937) established a single marketing system for agricultural commodities and turned the farmers' cooperatives into the commodity boards' financial agents, strengthening their power in the value chains and in the boards themselves (Vink \& Van Rooyen, 2009). Farmers' enrolment in cooperatives increased significantly, and the agricultural production under their management increased from $6 \%$ in 1919/1920 to 34\% in 1939/1940 and 71\% in 1970/1971 (Jacobs, 2013).

After the National Party came to power in 1948, this financial channel-from the Land Bank to the commercial farmers via the cooperatives-was maintained and strengthened. On the one hand, the Land Bank granted preferential loans to the farmers and their cooperatives in order to develop agricultural infrastructure and equipment, for example, the "silo-building loan programme" initiated in $1952 .^{8}$ The bank's portfolio and activities were boosted by tax exemptions ${ }^{9}$ and state guarantees-as such, Land Bank bills were recognized by the South African Reserve Bank as "prescribed assets." ${ }^{10}$ The bank was thus instrumental in financing the "modernization" of South African agriculture, especially in the 1960s, leading to significant productivity gains, but also the reduction of the number of farm units ${ }^{11}$ and the massive indebtedness of farmers (Webb, 2000). On the other hand, this financial channel was key to ensuring the support of white commercial farmers to the apartheid regime. Although the single marketing channel maintained low prices for agricultural commodities before 1948, the maize price increased by 33\% from 1949 to 1952 , benefiting those commercial farmers who remained (Bayley, 2000).

By the 1980s, financial markets and the South African white commercial farmers were thus connected through a specific financial channel, built around the Land Bank and the cooperatives. ${ }^{12}$ The state was directly involved in this banking intermediation model, maintaining the agricultural sector, interconnected at a distance to the financial industry, in order to achieve South African agricultural self-sufficiency and to maintain low food prices. ${ }^{13}$ In addition, this model was structured so as to guarantee the collective power of white commercial farmers over the agricultural sector. Cooperatives, directly controlled by farmers and especially by the larger ones, ${ }^{14}$ were involved in the management of both the single marketing channel and the Land Band financial channel (Bayley, 2000). Furthermore, they benefited from tax exemptions and public subsidies for building strategic agricultural assets (e.g., the "silo-building loan programme"), which they then managed, ensuring the commercial farmers had cheap access to agricultural services. Therefore, this institutional architecture enforced the control of commercial farmers over agro-food value chains.

In the 1980s and thereafter, this financial intermediation model faced a crisis on both the economic and political side. First, facing the slowdown of the global economy, ${ }^{15}$ the South African government initiated the deregulation of

8"Between 1952 and 1995, the bank advanced long-term loans totaling R444 million to agri-cooperatives for silo construction" (Jacobs, 2013: 31).

${ }^{9}$ As the Land Bank is not subject to the Bank Act.

${ }^{10}$ The Land Bank bills are "prescribed bonds," that is, the state, through the reserve bank, imposes a requirement on institutional investors (pension funds, insurance companies) to hold a significant proportion of these bonds in their portfolios (Jacobs, 2013).

${ }^{11}$ There were 118,097 farms in 1951, 91,153 in 1960, and 75,562 in 1976; at the same time, the average size of a farm increased from 736.5 to $1,134.4$ hectares (O'Meara, 1996).

${ }^{12}$ It was not a state monopoly, however, because commercial banks-such as Volkskas-also funded farmers and agricultural cooperatives, complementing the Land Bank's support through loans with different rates and maturities.

${ }^{13}$ Such political objectives must be understood in the larger perspective of the "mineral-energy complex" (Fine \& Rustomjee, 1997), that is, the dominant system of accumulation in South Africa built around the mining industry.

${ }^{14}$ Farmers who belonged to cooperatives appointed the board members who represented the farmers' constituency. This representation system was based on the farmers' production volume, whereas a regional quota system ensured the representation of the diversity of this constituency.

${ }^{15}$ This highlighted, among other things, the indebtedness of the South African farmers. 
the financial markets, following the report of the De Kock Commission in 1986 (Fine \& Ashman, 2013). Second, the political crisis led to the end of apartheid in 1994 and the end of political support to white commercial farmers. The Mandela government deregulated the agricultural sector, especially through the Marketing of Agricultural Products Act (1996), which abolished the Commodity Board system and overhauled the cooperatives' regional monopolies (Ortmann \& King, 2007).

These evolutions affected the structuration of financial institutions within the agricultural sector. First, the Land Bank's structure and role changed significantly. The Land Bank lost its fiscal and financial privileges in the late 1980s, adopting the regular banking industry standards (e.g., under the Basel Agreement) and being obliged to compete with other financial intermediaries. Then, in the 1990s, the mandate of the Bank changed radically as part of the country's land reform policies: Its primary focus became that of supporting and funding black emerging farmers. The collapse of land reform programmes, several corruption scandals, and the loss of market share led to even further restructuring of the bank towards more profitable and business-oriented activities in the mid-2000s. ${ }^{16}$

Second, the commercial banks-for example, ABSA, First National Bank and Standard Bank-reorganized their activities, creating specialized agricultural departments, managed by agricultural economists but according to the practices of the financial industry. Progressively, the commercial banks expanded their market shares in the agricultural sector, and in 2005 , they held $55 \%$ of the farmers' debts, compared with $17 \%$ for the Land Bank and $12.5 \%$ for the cooperatives (Vink \& Van Rooyen, 2009). At the end of the 2000s, commercial banks became even more directly involved in agricultural production through the development of precrop contracts for farmers (Ducastel \& Anseeuw, 2011).

Third, the cooperatives were also engaged in a restructuring process. Related to the 1993 amendment of the Cooperative Act, most of these cooperatives changed their status, becoming public companies ${ }^{17}$ (Bernstein, 2013). As such, their members became shareholders, receiving shares according to their volumes of production. In addition, such transformation opened the cooperatives' doors to new actors, starting with institutional investors and investment funds.

However, as will be seen in the next section, these transformations were and still are not straightforward and homogenous for all cooperatives, illustrating the hazardous transformation of finance-agriculture relations over the last two decades. To illustrate this, two specific case studies detailing the restructuring of cooperatives are presented.

\section{I THE TRANSFORMATION OF AFGRI: FROM A FARMERS' COOPERATIVE TO AN INVESTMENT FIRM}

\subsection{The private equity takeover (2014)}

Afgri was a grain cooperative known as the Oos-Transvaal Koöperasie (OTK), which grouped maize farmers and was based in the Mpumalanga province. In 1996, the Board of the cooperative decided to change its status to become a public company and to list it on the JSE. In 2014, the company was structured around three operational divisions: the agricultural services division (i.e., grain management, retail, and equipment), the food production division (i.e., animal feed, poultry, milling, oil, and protein), and the financial services division (i.e., insurance, loans, and broking; Afgri, 2013). ${ }^{18}$ In addition, Afgri has progressively expanded its activities beyond its traditional scope into other South African provinces (Free State, KwaZulu-Natal) and also abroad into Southern African countries such as Botswana, Mozambique, Zimbabwe, and Nigeria, as well as into Australia. ${ }^{19}$ Before the transaction, the main Afgri shareholders

\footnotetext{
${ }^{16}$ The bank was placed under the supervision of the Department of Finance in 2008, that is, a return to the pre-1996 organization model.

${ }^{17}$ South African Companies Act, 1998.

${ }^{18}$ In its annual reports, the company distinguishes between its "core operation (grain management and industrial foods sector operations) and its "value added operations" (retail, mechanization, and financial services; Afgri, 2012, 2013).

${ }^{19}$ In its corporate structure, Afgri separated its South African and foreign activities, the latter being grouped into a Mauritian holding (Afgri, 2013).
} 
were all professional asset managers, holding these public shares on behalf of institutional and individual investors. ${ }^{20}$ In addition, a BEE trust held $26.77 \%$ of Afgri's South African entity (Afgri, 2013).

The public company Afgri Limited delisted from the JSE on April 1, 2014, and became a private company after its takeover by a holding company named AgriGroupe. The process started on September 27, 2013, when Afgri's Board and AgriGroupe released a joint media statement about the intention of AgriGroupe to buy all the Afgri shares at a price of R7 per share, representing a total price for the company of R2.4 billion. ${ }^{21}$ As mentioned in that same media statement:

The offer is fully financed and represents a premium of $49 \%$ to the volume weighted average share price of R4.70 for the 30 trading days prior to Afgri's cautionary announcement on 06 September 2013 and a 22\% premium to the 52-week high of R5.75.

This arrangement was accepted by $99.9 \%$ of Afgri's shareholders on November 19, $2013 .^{22}$

AgriGroupe is a South African registered entity, controlled by a consortium based in Mauritius. The consortium is led by a pool of North American investors, holding $60 \%$ of AgriGroupe. ${ }^{23}$ The main investor in this pool is Fairfax Financial Holdings, a financial holding company listed on the Toronto Stock Exchange (Canada). Fairfax is mainly engaged "in property and casualty insurance and reinsurance and investment management." 24 As mentioned in a decision of the Competition Tribunal of South Africa, ${ }^{25}$

In relation to agricultural activities, Fairfax's subsidiary, namely Ridley Inc, is a commercial animal health nutrition business that manufactures and markets a full range of animal nutrition products. Ridley operates in North America, serving customers mainly in the United States and Canada.

Beside these North American investors, the AgriGroupe consortium is held $15 \%$ by South Africa's PIC, the asset manager of the South African Government Employee Pension Fund; ${ }^{26} 20 \%$ by a black economic empowerment trust named Bafepi Agri; and $5 \%$ by the Afgri management team, led by its CEO, Chris Venter. ${ }^{27}$ The Bafepi trust has been funded by PIC and is composed of various black individual entrepreneurs and consortia. ${ }^{28}$

During the transaction process, AgriGroupe insisted on the continuity of Afgri's business plan, reassuring all stakeholders (farmers, government):

AgriGroupe supports the strategic vision of the CEO and the process that he and his team have undertaken to restructure underperforming operations, strengthen its core grain management business and position the company for long-term investment and growth in South Africa and the rest of the African Continent. ${ }^{29}$

\footnotetext{
${ }^{20}$ Allan Gray (23.2\%), Sanlam Investment Management (6.8\%), Stanlib Asset Management (12.3\%), Momentum Asset Management (2.7\%), and the Private Investment Corporation (PIC) on behalf of the Government Employee Pension Fund (GEPF; 7\%).

${ }^{21}$ Afgri and AgriGroupe, joint media release Johannesburg, September 27, 2013.

${ }^{22}$ SENS, results of scheme meeting, November 19, 2013; a majority of $75 \%$ was requested for the transaction to be accepted.

${ }^{23}$ Business Day, November 6, 2013.

${ }^{24}$ Fairfax website, consulted on August 18, 2014.

${ }^{25}$ Competition Commission, Case No. 017939, April 15, 2014.

${ }^{26} \mathrm{PIC}$ is a public entity under the supervision of the Department of Finance. It invests mainly on behalf of the GEPF, the pension fund of South African public servants, also under the tutorship of the Department of Finance. Recently, these entities stated their intention to increase their developmental investments, especially in the agricultural sector (address by John Oliphant, GEPF Principal Executive Officer, Cape Town Press Club, April 23, 2013).

${ }^{27}$ Afgri and AgriGroupe, joint press statement, March 31, 2014.

${ }^{28}$ Afgri, circular to shareholders, October 22, 2013.

${ }^{29}$ Afgri and AgriGroupe, joint media release, September 27, 2013.
} 


\subsection{From OTK to Afgri: when farmers become shareholders and shareholders become farmers (1996-2014)}

To better understand the reasons and motivations behind the takeover, it is important to analyse the company in a longer perspective and follow the different steps of its transformation. In 1994, to face the new situation and preserve the interests of commercial farmers, most of the cooperatives resolved to become public companies, with their members becoming the shareholders of these "new" entities. The boards of these cooperatives then chose different company statuses and strategies, with OTK being the only one to opt for a listing on the JSE. This listing was a way to protect the cooperative from the intrusions of the new government. In addition, after few months, OTK's share price on the JSE increased significantly, "from an issue price of 192 c to a high of over $600 c,{ }^{\text {"30 }}$ resulting in the farmer-shareholders receiving a good premium from their shares. The end of the 1990s was characterized by a consolidation process when former cooperatives merged: OTK expanded its business by buying another former cooperative, SentraalOos, based in the Free State.

Until 2000, all the OTK board members, with the exception of the CEO, were farmers, which resulted in the company being run in the "same old way," and the board members considered themselves to be farmers' delegates:

Being director in a co-op is about representing the farmers and it is different to be a director in a Board company where you have to represent the shareholders. ${ }^{31}$

However, as a public company, OTK came under increasing scrutiny by institutional investors, who were acquiring more shares in the company. In 2000, the South African private equity firm BRAIT Capital acquired 19\% of OTK's shares on the JSE. Together with investment management firm Allan Gray, which had already retained 34\%, it engaged in a restructuring process of the company. ${ }^{32}$ This takeover happened while the OTK share price was dropping below 400c and critics concentrated on the company's management and its negative impact on group profitability.

RAIT started by substituting most of the farmer-directors on OTK's board with their own directors. Only four farmers remained on the board, and the newly appointed directors had more financially oriented backgrounds. ${ }^{33}$ They also changed the managing team of the company ${ }^{34}$ in order to implement a more shareholder-friendly value approach. In addition, during the first 4 years (2000-2004), BRAIT Capital implemented major changes in the company's management. First, they decided to sell its debtors' book to Wesbank and the Land Bank for R921 million, which gave them the capital to reward the shareholders with a dividend of R2.45 per share. ${ }^{35}$ In parallel, they also sold OTK's milling division ${ }^{36}$ and other "noncore businesses" (e.g., an egg-producing entity), and they acquired two other former cooperatives, ${ }^{37}$ and endeavoured to develop a branch for cotton production in other African countries. ${ }^{38}$ They also reduced the company's staff by 1,200 to about 2,800 employees. Finally, in 2002, they changed the company's name, becoming Afgri. ${ }^{39}$

\footnotetext{
30“Unlocking value," Finance Week, February 16, 2001.

${ }^{31}$ Interview with J. J Ferreira, former Afgri board member, Warden (SA), July 24, 2014.

32“Unlocking value," Finance Week, February 16, 2001.

${ }^{33}$ Mervyn King (corporate attorney and chairman of the King Committee on Corporate Governance), Anthony Ball (group chief executive of BRAIT), Eduardo Gutierrez-Garcia (principal at BRAIT's Private Equity Fund III), MJ van der Merwe (managing director at Allan Gray), Neill Davies (executive and director of BRAIT), SC Marais (executive chairman of Allan Gray; Afgri, 2002).

${ }^{34}$ Hiring Graham Ebedes and Jeff Wright from Tiger Brands.

${ }^{35}$ OTK sells debtors' book for R921 m, Reuters, February 27, 2001.

${ }^{36}$ OTK sells its maize mills to management, SENS, May 27, 2001.

${ }^{37}$ The "Natal Agricultural Cooperative Limited" in KwaZulu-Natal and "Laeveld Korporatiewe Beleggings Beperk" in Northern Mpumalanga (Afgri, 2004).

${ }^{38}$ Clarke Cotton.

${ }^{39}$ OTK Holdings Limited: Change of Name, SENS, July 15, 2002.
} 
The transformation process has been largely driven by the implementation of financial ratios and benchmarks, especially the adoption of an "economic value-added" (EVA) ${ }^{40}$ model (Afgri, 2002), which focused primarily on shareholders' remuneration, ${ }^{41}$ and, as stated in the 2002 annual report, "Investments that destroyed shareholders' value were sold." In addition, they implemented an EVA-based mechanism for the remuneration of the directors (Afgri, 2002). Such instrumentality also drove a change in their capital structure. Indeed, as "OTK" had previously used only its own capital, they then started borrowing money and increased the company's indebtedness. In short, BRAIT Capital restructured the company according to "shareholder value" mainstream principles, that is, focusing on the core businesses, rationalization according to the EVA, and reduction of staff, in order to achieve a quick reward for their investors.

As mentioned, most of the farmer-directors were removed from the OTK Board in 2000. There were four farmerdirectors until 2006, only two from 2007 to 2011, and none after that. Such marginalization within the board reflects the progressive loss of control over this agribusiness firm and its assets by the white commercial farmers, in favour of these institutional investors. During this period, several farmers left the company because they no longer identified with it:

They left because they had the feeling that the company was now run by people from the city, from Johannesburg ... and there were also cultural and language aspects; in BRAIT they were only Englishspeaking, while $95 \%$ of the farmers are Afrikaans-speaking. ${ }^{42}$

The reduction of staff on the ground and the selling of several of Afgri's assets (e.g., mills) was also perceived as being a reduction in the level of services for farmers, for the sole benefit of shareholders' remuneration.

In 2004, BRAIT left the company, selling its shares to public shareholders and to a black economic empowerment (BEE) trust, the "Agri Sizwe Trust." ${ }^{43}$ No majority shareholder has held a controlling block since BRAIT left. From 2005 to 2013, the company's evolution was characterized by the increasing role of the Afgri management team and its empowerment as an autonomous element of "corporate capital," positioned in between commercial farmers and financial industry. Indeed, in 2008 , Chris Venter ${ }^{44}$ became the CEO of the Afgri group and initiated changes in the management team and tended to centralize the managing structure. This management team maintained focus on shareholder value principles and evolving "market requirements," ${ }^{45}$ but at the same time also moved closer to the white, particularly Afrikaner, commercial farmers. This re-emphasized their "agricultural backgrounds" and is reflected through various farmers' initiatives, such as the AgriSA ${ }^{46}$ project in the Democratic Republic of Congo. In 2010, the Afgri BEE Trust was restructured as the Afgri Black Employees' Trust, acquiring $100 \%$ of the BEE entity, while the

\footnotetext{
${ }^{40} \mathrm{EVA}=$ the net operating profit after taxes - the percentage cost of capital $*$ total capital.

41"By ensuring that Return on equity invested exceeds the group's weighted average cost of capital."

${ }^{42}$ Interview with J.J. Ferreira, Warden (SA), July 24, 2014.

${ }^{43}$ This first Afgri BEE trust was composed of individual black entrepreneurs, black emerging farmers' organizations (i.e., the National Emergent Red Meat Producers' Organization and the National African Farmers' Union) and the Afgri black employees' trust (Izitsalo Employee Investments).

44"Chris obtained valuable merchant banking experience during seven years with Standard Merchant Bank (now Standard Corporate and Investment Bank), where he was primarily involved with trade and project finance. He concluded his employment with SCIB as head of the Export Credit Finance Department. Chris joined Absa Corporate and Merchant Bank in 1999 as team leader of the Structured Trade and Commodity Finance Team. In total, he spent seven years with Absa Corporate and Merchant Bank of which three years were in New York as head of the Structured Trade Finance Unit focusing on commodity financing in Latin America. On returning to South Africa in December 2004 he was appointed as head of the Global Structured Trade and Commodity Finance Team. In June 2006 Chris joined AFGRI as managing director of AFGRI Financial Services and Insurance and assumed responsibility for the group's Treasury Division. Subsequently, he has held various director positions within AFGRI, including chairman of Agricola and AFGRI Western Cape. He was appointed to the board of AFGRI Operations Limited in July 2007 and appointed as group chief executive officer with effect from 1 October 2008" (Afgri, 2013).

${ }^{45}$ For instance, they followed the recommendations of the King III Report on Corporate Sustainability, introducing, for example, a sustainability component in their annual report.

${ }^{46}$ The representing body of South African commercial farmers, heir to the "South African Agricultural Union," a white farmers' union during apartheid.
} 
external partners exited. Such restructuring through the promotion of a black minority illustrates the increasing control over the company by professional managers. ${ }^{47}$

During this period, Afgri's strategy tended to become more and more focused on grain management and the food industry, with the acquisition of new assets in these two areas. ${ }^{48}$ They restructured what they considered their "valueadded operations" through businesses sales ${ }^{49}$ and mergers. ${ }^{50}$ In 2012, the company also entered into a partnership agreement with the Land Bank, the South African governmental development finance institution for the agricultural sector, in terms of which Afgri sold both its farmers' debtors book and its corporate lending book to the bank (Afgri, 2012). Through this agreement, Afgri will continue to manage these books, but on behalf of the Land Bank that owns and funds it. ${ }^{51}$ Finally, from 2012, the expansion into Africa became a strategic dimension, ${ }^{52}$ illustrating the evolution of the company as an investment firm, operating north of the Limpopo River.

\subsection{The battle for Afgri's assets}

In 2013, the company experienced financial difficulties, partly due to losses within its poultry operations. Its share price dropped from around $555 \mathrm{c}$ at the beginning of the year to $412 \mathrm{c}$ at the end of June. However, the company remained attractive enough for AgriGroupe to offer a bid of R7 per share and R2.4 billion for the entire company. Such attraction and the appetite exhibited by these financial investors seem to result from four different factors.

First, as we mentioned before, the company as a former cooperative, and through its various acquisitions, had accumulated strategic agribusiness assets, especially silos. ${ }^{53}$ The silo market is locality based, and as the costs of acquisition-and thus of entry-are very high, Afgri holds a regional monopoly position in Mpumalanga, northern KwaZulu-Natal and northern Free State. Many financial analysts highlighted the gap between the company's net asset value and its market price before the transaction. ${ }^{54}$

Second, as mentioned before, Afgri entered into an agreement with the Land Bank in 2012. Through this partnership, Afgri became the Land Bank's preferential intermediary for commercial and emerging farmers. Performing such functions gave the company access to the preferential loan rates of the bank, resulting in better margins. ${ }^{55}$ Not only does the Land Bank's sponsorship give Afgri financial incentives and a secure position, it also positions it (and the bank) as a key player in the transformation process of the sector.

Third, Afgri had progressively developed its "African footprint" (Afgri, 2013), especially through its Mauritian platform, which groups its foreign investments. The "off-shorization" of these foreign activities allows the company to avoid the South African tax regime and fluidifies its financial flows. AgriGroupe has underlined its intention several times to expand the African dimension of AgriGroupe's businesses. ${ }^{56}$

Finally, Afgri was probably the most accessible company for a buyout on the South African agro-food market. As detailed above, the listing of Afgri had turned the company into a "market-friendly" company, fulfilling the mainstream shareholders' requirements in terms of governance and structure. Conversely, as will be shown in the last section of

\footnotetext{
47"Afgri enriches employees via a broad-based BEE deal," Afgri, July 29, 2010.

${ }^{48}$ Rossgro Chicken in the poultry industry.

${ }^{49}$ Clark Cotton in 2006.

${ }^{50}$ They disposed of their retail branch in a new joint venture entity, in partnership with Senwes.

51“Land Bank acquires AFGRI's corporate lending book in landmark transaction," Land Bank, July 11, 2012.

${ }^{52}$ Construction of bunkers facilities in Zambia; acquisition of an agricultural service provider in Nigeria.

${ }^{53}$ Afgri holds slightly more than $25 \%$ of the silos in South Africa (Competition Tribunal, Case No. 17/LM/Mar04).

54"Takeover discussions under way at ailing conglomerate Afgri," Business Day, September 9, 2013.

${ }^{55}$ As the agribusiness head of a major South African commercial bank states "The Land Bank doesn't have to pay tax or go through processes such as the Financial Intelligence Centre Act, which sharply drives up the costs of commercial banks. But commercial banks have to compete with them and I believe that's unfair" ("Farmers in bid to block R2.5 bn Afgri sale," Business Day, November 13, 2013).

56"We will support management's strategic vision for African food security through the development of critical supply chain infrastructure, logistics solutions and financial services for both smallholding and commercial farmers in Africa" (Afgri and AgriGroupe, joint press statement, March 31, 2014).
} 
this paper, the other former cooperatives holding similar assets are still largely controlled by farmers' blocks, and as such are protecting farmers' interests.

Other potential investors emerged during the transaction process, proposing different deals with different purposes. The African Farmers' Association of South Africa (AFASA), a black farmers' union claiming to represent 12,000 farmers, ${ }^{57}$ both emerging and commercial, have identified Afgri as strategic company and asset, ${ }^{58}$ particularly for the empowerment of black farmers in agricultural value chains:

The rationale for acquiring Afgri and using it as a base for further direct black participation across the entire agricultural value chain in South African and beyond South Africa's borders. However, the AFASA consortium has from the onset made it very clear that it sees South Africa as home and that the needs of South Africa and the food security imperatives in the country must come first including ensuring that vehicles like Afgri become transformative agents in what continues to be a very closed sector to blacks. ${ }^{59}$

As such, they firstly endeavoured to raise capital in order to directly buy the company out. However, as the AgriGroupe transaction moved on, they started a campaign against the deal ${ }^{60}$ and engaged in a legal case with the national competition authorities, ${ }^{61}$ while securing support from the SA Communist Party. ${ }^{62}$ This led to several government departments raising concerns about the transaction with the competition authorities.

The conflict over the Afgri deal and the coalitions that emerged reflect the tensions and conflicts surrounding the ongoing postapartheid agricultural transformations and the role the financial industry plays in this process of reconfiguring capitalistic structures. On the one hand, AgriGroupe succeeded thanks to the commitment of Afgri's management team, which emphasized its African expansion project in development since 2012 (Afgri, 2012, 2013). Indeed, the two main institutional investors, Canadian Fairfax Financial Holdings and the South African PIC, have a very limited background in agriculture and agribusiness, if any, and rely on the management team for value creation in the sector. The same could be said about the BEE Isibaya Trust that is involved, which is formed around black entrepreneurs who are part of an "incumbent black capital elite" (Marais, 2011) and is promoted through the actual BEE model (Freund, 2007). Finally, the apparent neutrality of commercial farmers and their representative body regarding this transaction is worth mentioning here.

On the other hand, AFASA failed to group institutional investors around its project for using Afgri to further the empowerment and the development of black farmers. According to Andrew Makenete, one of AFASA's economic advisers, this is attributable to the misunderstanding of the South African market by these foreign investors:

For the poultry operation, for instance, as black, I would get access to new contracts, like KFC, which is looking for such partners. However, this is something Americans do not understand; because unlocking the value in South Africa is a different game. ${ }^{63}$

Then, the South African government was much divided and ambiguous in its positioning and support towards AFASA. Several departments endeavoured to prevent the competition authorities from approving the deal and raised AFASA's concerns. ${ }^{64}$ However, on the other hand, PIC had accepted "AgriGroupe's" bid, while the Land Bank-as a

\footnotetext{
${ }^{57}$ AFASA was born from a scission in the "National African Farmers' Union," which was the first black farmers' union in South Africa.

${ }^{58}$ As Chabane (2004) notes about the maize sector, "the vertical integration and the combination of related activities (which) makes the silos so pivotal in the market."

59"AFASA's reaction to media reports about Afgri's transaction," AFASA, October 14, 2013.

60"Why takeover of Afgri must be stopped?" AFASA, October 1, 2013; "Black farmers aim to block Afgri takeover," Business Day, October 30, 2013.

61"Farmers in bid to block R2.5 bn Afgri sale," Business Day, November 13, 2013.

${ }^{62}$ SA Communist Party press release, December 1, 2013.

${ }^{63}$ Interview with Andrew Makenete, special adviser to AFASA, Pretoria (SA), May 27, 2014.

${ }^{64}$ The concerns were about a foreign entity controlling $25 \%$ of South African silo facilities and the potential consequences for food prices, and the risk of Afgri moving to Mauritius because of tax benefits and the undervaluation of Afgri.
} 
privileged partner of "Afgri"-had been totally absent from this debate. Finally, an agreement was reached between the departments and Afgri's shareholders ${ }^{65}$ and the government endorsed the transaction. This support raised questions about the model for agricultural development and empowerment promoted by the government-as detailed in Section 3.4 hereafter.

Afgri's trajectory gives us an original example of a firm's financialization and its impact on the firm's governance and organization. First, the establishment of shareholder value principles within Afgri led to a progressive marginalization of the commercial farmers, who moved from being cooperative members to becoming shareholders, and then simple clients. Second, we note the empowerment of professional managers who acquired increasing room to manoeuvre with regard to Afgri's public shareholders and the commercial farmer community. The AgriGroupe buyout is the culmination of this autonomization process, turning Afgri into a private company. Such reconfiguration of the managers' profile and the convergence of interests between them and institutional investors has been analysed elsewhere as a major financialization impact on the capitalist firm (Fligstein \& Shin, 2007). Third, white commercial farmers, particularly the smaller and medium-sized ones, tend to be marginalized in the South African value chains. ${ }^{66}$ However, Afgri's management team tends to preserve them, or at least some of them, as they rely on this group for their African expansion strategy. Indeed, if institutional investors rely on professional managers for the value extraction from corporates, they both rely on agrarian capital for value extraction in the African agricultural sectors. Finally, the emerging (black) small-scale farmers remain at the margin of this pattern of accumulation. As such, this Afgri case study shows the changing structures and alliances underlying the pattern of accumulation in the agro-food value chains, and the attempts from different forms of capital to secure their profit shares.

\subsection{The resistance of commercial farmers: The Zeder case study}

Afgri's trajectory is unique in the sector, as it is the first, and so far the only, former cooperative to be listed on the JSE. Other similar entities, with similar assets but positioned in other geographical areas, have adopted different conversion strategies. In light of the Afgri experience-its quotation and the marginalization of farmers-they became public companies but progressively implemented specific protection mechanisms, such as private sharetrading platforms. Recently, financial investors have been assessing these entities but have been confronted by these mechanisms. These confrontations highlight a different process compared with the Afgri one and illustrate the coexistence in South Africa's agricultural sector of different financialization processes and intensities. One particular case, that of Zeder, is now considered in order to better understand these resistance and adaptation strategies.

Zeder is a holding company, focusing on the agricultural, food, food processing, and beverage-related sectors (Zeder, 2009), which describes itself as a long-term investor and is listed on the JSE. It was set up in 2006 by the PSG Group, a South African listed investment holding company and promoter of "Afrikaner capital"67 (Fine \& Ashman, 2013). With the exception of the PSG group, which holds slightly more than $42 \%$, Zeder's other shareholders are public entities listed on the JSE. From its inception, Zeder's strategy focused on investments in former cooperatives in order to "assist" their transition and to benefit from "arbitrage opportunity" (Zeder, 2012). As described by Jannie Mouton, while recognizing the gap between the cooperatives' net asset value and their share market value, they focus on

\footnotetext{
${ }^{65}$ Competition Tribunal, Case No. 017939, April 15, 2014.

${ }^{66}$ According to one of South Africa's biggest farmers, Kallie Schoeman of Schoeman Boerdery: "It is natural, simply capitalism ... you must get bigger, get better, or get out." (Financial Mail, January 19, 2012), noted in Bernstein (2013).

${ }^{67}$ Founded in 1995 by Jannie Mouton and based in Stellenbosch, its major shareholders are its directors (36.6\%); Steinhoff, a furniture production company led by Markus Jooste (19.6\%); other relatives and friends (10.1\%); and Thembeka Capital (5.2\%; "BEE firms need to take a leaf out of PSG's book," Business Live, June 25, 2013). In addition, PSG annual meetings are mostly held in Afrikaans and the shareholders present are mostly Afrikaners (observation by the author).
} 
The complete transformation of cooperatives to profitable public companies with good management, sweating the rich assets and shares that are freely tradable, reflecting a share price that is closer to fair value (Zeder, 2008).

Indeed, Zeder's appetite has been motivated by the fact that former cooperatives are "profitable and asset rich with a loyal client base" (Zeder, 2008), the value of which has been locked in because of "restrictions on transferability of the shares" and "non-profit oriented management." 68 To "unlock" this value, Zeder acquired "noncontrolling strategic stakes" in these unlisted entities ${ }^{69}$ (Zeder, 2008). In the following years, Zeder engaged in a financial rationalization of these companies. However, in 2012, they announced a radical change in their investment strategy ${ }^{70}$ and sold most of this portfolio.

Indeed, they achieved very mixed success. On the one hand, Zeder had succeeded in its unbundling strategy with Kaap Agri, disposing of its Pioneer Foods interests to a newly created entity named Agri Voedsel Beleggngs (Zeder, 2012). ${ }^{71}$ These unbundling operations generated considerable returns for the shareholders. On the other hand, as stated in their 2012 annual report:

In many other co-ops we have found that it may still take a long time for them to become more shareholder orientated.

Therefore, in 2014, they disposed of all their stakes in the former cooperatives, except Kaap Agri.

These former cooperatives had been converted into public companies in the late 90s. But rather than getting listed on the JSE, it was decided to create their own share trading "over the counter" platform. Such mechanism gives the company an oversight of its ownership structure, as it directly manages such platform, and limits the risks of takeover by institutional investors because of the low liquidity of the bonds. In addition, many former cooperatives had progressively implemented farmers' share controlling blocks in order to secure their positions. Such blocks often take the form of holdings or investment companies, with restrictive share trading options. ${ }^{72}$

Although Zeder acquired stakes in these entities and endeavoured to introduce a financial rationalization plan, tensions mushroomed with these controlling blocks. One of the major sources of tension emerged in several cases around the disposal of specific branches or services. Indeed, Zeder pushed for refocusing on what it considered as being the companies' core business, often grain storage, and for selling off the other activities, particularly the farmers' debtor books, considered as a low-profit and capital-intensive business. On the other hand, shareholder-farmers were concerned about these disposals, as most of these cooperatives gave them access to preferential loans or debts, compared with what commercial banks offered. Thanks to their majority on the board and the share trading restrictions,

\footnotetext{
68"Most were cooperatives, some between 50 and 100 years old and there was no motivation for them to make a profit. Their sole purpose was to sell goods at low prices to members who were also the owners" (Interview with Jannie Mouton, Farmers' Weekly, February 10,2009$)$.

${ }^{69}$ In 2008, Zeder owned such positions in MGK Business Investment Limited (29.8\%), based in the North West Province; Kaap Agri Limited (33.6 \%) in the Western Cape; Suidwes Investment Limited (15.5\%) in the North West Province; KWV Limited (20.8\%) in the Western Cape; NWK Limited (4.4\%) in the North West Province; BKB Limited (3.3\%) in the Eastern Cape; Senwes Limited (5.8\%) in the Free State; KLK Landbou Limited (10.0\%) in the Northern Cape; Tuinroete Agri Limited (5.9\%) in the Eastern Cape; and OVK Operations Limited (8.1\%) in the Free State.

${ }^{70}$ Through the acquisition of controlling stakes, with a focus on southern Africa, which is no longer considered to be the "dark continent" but rather "a land of opportunity" (Zeder, 2012), and they directly invested in primary production (Chayton in Zambia).

${ }^{71}$ The same happened with the unbundling between the KWV operations and its share in the South African wine company Distell, which had been grouped into Capevin Holdings (Zeder, 2010).

${ }^{72}$ For instance, in the case of the NWK Holdings Limited,
}

this company may not dispose of shares held in NWK Limited without a prior resolution by its members, approved by $75 \%$ of all the votes of its members, if the disposal of shares will lead to its interest in the voting power of NWK Limited decreasing to below 51\%.Therefore, Senwesbel held 51.09\% in Senwes in 2013 (Senwes, 2013); Suidwes Holding Limited sold $51.06 \%$ in Suidwes in this same year (Suidwes, 2013); SA Besproeiings Korporasie Limited held $51.33 \%$ in MGK Limited; and "NWK Holdings Limited" helds $59 \%$ in "NWK Limited." 
they could prevent such a strategy, thereby maintaining Zeder as a minority shareholder. From 2012, Zeder began to dispose of its interests in these companies, and farmer-shareholders' blocks often bought back these shares, reaffirming their authority and control. ${ }^{73}$

However, when several of these former cooperatives are assessed, one can observe the recent changes in their management and overall structure, which can be analysed as constituting an import of a financialized conception of the firms. For instance, in February 2017, Senwes-the second largest former agricultural cooperative-listed on the newly established South African stock exchange market, ZAR X, with the objective to unlock value for shareholders as stated by the company's CEO:

Being the first to list on South Africa's new stock exchange reflects our ethos of innovating to the benefit of our stakeholders and the country in general (...) ZAR X's fresh and practical approach to listing has given us a new, affordable, and very low risk avenue through which to drive our strategy and, in the process, unlock additional value for our existing shareholders. Jointly, we're breaking new ground for agriculture in South Africa. $^{74}$

Senwes executives and historical shareholders adopt the very same strategy as financial players. Indeed, simultaneously, Kaap Agri, another former agricultural co-op still held in majority by Zeder, has since listed on the JSE for the very same reasons ${ }^{75}$. Therefore, Senwes' major shareholder-farmers consider (and maybe even prioritize) financial revenue streams (dividend and share price increase) together with agricultural operational revenues.

Such transformations raised questions, while noting the failure of institutional investors and investment companies to fully take over these companies. However, it seems that such a strategy is being progressively adopted by the dominant shareholder-farmers and that the professional managers of these companies are recognized as providing the most profitable business strategy.

By means of specific mechanisms that ensure their cohesion and collective power, white commercial farmers have been able to maintain their control over these companies and their agricultural assets. Indeed, even when confronted by Zeder, they were able to maintain their control over these assets and to block what they considered as being a threat to their farmers' collective interests, while it could benefit them as shareholders. However, through Zeder's influence and the change in the industry, there is evidence of an indirect financialization, or a financialization from inside, of these companies, as the dominant farmer-shareholders tend to reframe their business strategy, progressively adopting a financialized conception of the firm and a shareholder perspective.

\section{4 | CONCLUSION}

Under the apartheid regime, South African agricultural cooperatives were key institutions, positioning themselves between the farmers and the Land Bank. On the one hand, this model supported agricultural "modernization" in order to achieve South Africa's self-sufficiency and to maintain low food prices. As such, the Land Bank-cooperative financial channel was a component of the "mineral-energy complex" (Fine \& Rustomjee, 1997) as it gave the mining industry the opportunity to maintain low wages. On the other hand, this intermediation model guaranteed the alliance between the commercial farmers' elite-that is, South Africa's agrarian capital-and the apartheid state. This intermediation model has been contested since the 1980s and cooperatives have engaged in a restructuring process, illustrating the changing environment and the new balance of power among farmers, financiers and the state.

In this context, cooperatives have gone through different transformation paths over the last two decades. Afgri, once the bigger cooperative, resolved to list itself on the stock exchange. After few years, a pool of institutional

\footnotetext{
73"Since the controlling interest in the business is held by a shareholding structure with a long-term agricultural vision, the other partners have to be aligned accordingly" (Senwes, 2012).

${ }^{74}$ Senwes, "ZAR X'S first listing kicks off new era in South African agri-business," February 21, 2017.

${ }^{75}$ Business Day, "Kaap Agri sees good demand at listing," June 27, 2017.
} 
investors took control over Afgri and implemented a corporate rationalization according to shareholder value principles and devices. One of the consequences has been the empowerment of companies' managers in the decision-making process at the expense of farmers. In 2014, these managers concluded an alliance with a pool of private investors to take over the company. Cooled by the Afgri experiences, white commercial farmers in other areas adopted a much more conservative strategy to retain co-ops in their hands. Although they converted the cooperatives into public companies in the 1990s, they ensured the farmers' control through trading restrictions. Recently, these companies attracted private institutional investors who endeavoured to "unlock the value" in these companies through restructuring, abandonment of trading restrictions, and unbundling strategies. Although these takeover attempts partly failed, it seems that some of these companies are currently engaged in reframing their business strategy, which tends to become more and more financialized.

The financialization of South Africa's agricultural sector appears both limited in scale and with varying levels of intensity according to the organization concerned. First, besides Afgri and Kaap Agri, the direct control of financial actors over agricultural activities is relatively limited in South Africa, as few former cooperatives are presently directly held and managed by institutional investors. However, this observation has to be nuanced as financial institutions and investment funds also target other agricultural assets in the country, for example, farms or agribusiness small and medium entreprises (SMEs) (Ducastel \& Anseeuw, 2017). Second, beyond direct financial control, shareholders value governance mechanisms and conceptions circulate and are re-appropriated by nonfinancial actors. Such circulation is boosted not only by funds and companies' investments in the sector but also by commercial banks or even the Land Bank. Therefore, along productive revenue, farmers and former cooperatives leverage financial revenue, that is, dividends. The articulation and complementarity between both revenue streams varies according to actors' capital and resources.

Through the two examples cited, it also appears that financialization processes rely on, and are framed by, alliances and conflicts among financiers, managers, and farmers, as well as those within these groups of actors. As such, financialization is a political process in which actors, from both the financial industry and the agricultural sector, tend either to reinforce their domination or to challenge incumbents (Fligstein, 1996). In the South African sector, a small group of farmers who own the larger farms and most of the cooperative shares ${ }^{76}$ are able to partner with investment funds or to reclaim for their own profit financialized business strategies. On the contrary, small commercial farmers and black emerging farmers are more and more marginalized. Through this study, the South African State appears as an active promoter of financialization, both indirectly and directly. Indirectly, as stated by Martin and Clapp (2015: 2):

Whereas the state has taken explicit measures to ensure that agriculture was supported by finance at various times, more recently states have instead ensured that financial markets were supported by agriculture. The state, through its various interventions at the intersection of agriculture and finance, has shaped the conditions that today make agriculture an attractive site for investment by private financial actors.

Beyond these regulatory frameworks, the South African State is also directly involved in the recent transformations through public and para-public financial institutions' investments. For instance, the Public Investment Corporation, a public entity managing the savings of public servants, was one of the major investors in and promoters of the 2014 Afgri takeover. This deal illustrates the current conception of the country's economic developmental policy. Indeed, the South African government tends more and more to promote investment funds-such as BEE trusts-as a "political instrument" (Lascoumes \& Le Galès, 2007) for (especially black) empowerment and development. As such, it promotes redistribution from above ${ }^{77}$ with the main beneficiary of such projects being the black financial elite, whereas the rural or agricultural beneficiaries' voices are marginalized and redistribution minimalized.

\footnotetext{
${ }^{76}$ For example, Senwesbel, that is, the holding entity owning a majority of Senwes's shares, is controlled by only 15 large-scale farmers.

${ }^{77}$ In opposition to "accumulation from below" (Cousins, 2013).
} 
Fine and Ashman (2013) characterize financialization in South Africa by the increasing control of financial conglomerates over economic structures and by the important role of financial revenue in the gross domestic product. The analysis of the mutation of the former cooperatives leads to another characteristic, that is, the diffusion of financial logics, actors, and devices beyond the financial sector and market (Ducastel, 2017). In this "financialized mineralenergy complex," agriculture is integrated into the national regime of accumulation as an "emerging asset class," among others. Adopting this framework, the postapartheid state promotes a land reform model based on the redistribution of dividends, making the beneficiaries not the "emerging farmers," but the "emerging shareholders."

\section{ORCID}

Antoine Ducastel (iD http://orcid.org/0000-0001-6343-5173

\section{REFERENCES}

Afgri. (2002). Annual report. Available online at: http\%3A\%2F\%2Fwww.africanfinancials.com\%2FReport.aspx\%3Fafr_year\% 3D2002\%26amp\%3BCountryDOMAIN\%3Dza\%26amp\%3BCshortName\%3DAFR.

Afgri. (2004). Annual report. Available online at: http://www.afgri.co.za/downloads/afgri-annual-report-2004.pdf.

Afgri. (2012). Integrated annual report. Available online at: http\%3A\%2F\%2Fwww.africanfinancials.com\%2FReport.aspx\% 3Fafr_year\%3D2012\%26amp\%3BCountryDOMAIN\%3Dza\%26amp\%3BCshortName\%3DAFR.

Afgri. (2013). Integrated annual report. Available online at: http://www.afgri.co.za/financials/2013/AFGRI_Annual_Report_ 2013.pdf.

Aglietta, M., \& Rigot, S. (2009). Crise et rénovation de la finance. Paris: Odile Jacob.

Anseeuw, W., Liebenberg, F., \& Kirsten, J. (2015). Agrarian reform in South Africa: Objectives, evolutions and results at national level. In H. Cochet, W. Anseeuw, \& S. Fréguin-Gresh (Eds.), South Africa's agrarian question (pp. 28-51). Pretoria: HSRC Press.

Bayley, B. (2000). A revolution in the market: The Deregulation of South African agriculture. Oxford: Oxford Policy Management.

Bernstein, H. (2013). Commercial agriculture in South Africa since 1994: 'Natural, simply capitalism'. Journal of Agrarian Change, 13(1), 23-46.

Boyer, R. (1990). Regulation theory: A critical introduction. New York, NY: Columbia University Press.

Boyer, R. (2000). Is a finance-led growth regime a viable alternative to Fordism? A preliminary analysis. Economy and Society, 29(1), 111-145.

Chabane, N. (2004). Markets, efficiency and public policy: An evaluation of recent influences on price in the maize market and government responses. Transformation: Critical Perspectives on Southern Africa, 55, 55-77.

Christophers, B. (2015). The limits to financialisation. Dialogue in Human Geographies, 5(2), 183-200.

Clapp, J., Visser, O., \& Isakson, R. (2017). The complex dynamics of agriculture as a financial asset: Introduction to symposium. Agriculture and Human Values, 34(1), 179-183.

Cochet, H. (2015). The planned destruction of 'black' agriculture. In H. Cochet, W. Anseeuw, \& S. Fréguin-Gresh (Eds.), South Africa's agrarian question (pp. 12-27). Pretoria: HSRC Press.

Cousins, B. (2013). Smallholder irrigation schemes, agrarian reform and "accumulation from above and from below" in South Africa. Journal of Agrarian Change, 13(1), 116-139.

Ducastel, A. (2017). Le capital-investissement comme instrument de l'action publique ou la financiarisation du développement en Afrique subsaharienne. Politique Africaine, 144, 135-155.

Ducastel, A., \& Anseeuw, W. (2011). La libéralisation agricole postapartheid en Afrique du Sud: Nouveaux modèles de production et d'investissement. Afrique Contemporaine, 237, 57-70.

Ducastel, A., \& Anseeuw, W. (2016). Agriculture as an asset class: Reshaping the South African farming sector. Agriculture and Human Values, 33(1), 1-11.

Ducastel, A., \& Anseeuw, W. (2017). Investissements fonciers à grande échelle et financiarisation de l'agriculture: une analyse par les filières agro-financières. In G. Allaire, \& B. Daviron (Eds.), Transformations agricoles et agroalimentaires: Entre écologie et capitalisme (pp. 257-275). Versailles, Editions Quae.

Fairbairn, M. (2014). 'Like gold with yield': Evolving intersections between farmland and finance. Journal of Peasant Studies, 41(5), 777-795.

Fine, B., \& Ashman, S. (2013). Neo-liberalism, varieties of capitalism, and the shifting contours of South Africa's financial system. Transformation, 81(82), 145-178. 
Fine, B., \& Rustomjee, Z. (1997). The political economy of South Africa: From minerals-energy complex to industrialisation. Boulder, CO: Westview Press.

Fligstein, N. (1996). Markets as politics: A political-cultural approach to market institutions. American Sociological Review, 61(4), 656-673.

Fligstein, N., \& Shin, T. (2007). Shareholder value and the transformation of the U.S. economy, 1984-2000. Sociological Forum, $\mathrm{n}^{\circ} 22,399-424$.

Freund, B. (2007). South Africa: The end of apartheid \& the emergence of the "BEE elite". Review of African Political Economy, 34(114), 661-678.

Isakson, R. (2014). Food and finance: The financial transformation of agro-food supply chains. Journal of Peasant Studies, 41(5), 749-775.

Jacobs, J. (2013). History of the Land Bank: Financing agriculture for 100 years. Pretoria: Land Bank.

Jones, S., Vivian, R. W., \& Vink, N. (2010). South African economy and policy, 1990-2000: An economy in transition. Manchester: Manchester University Press.

Krippner, G. (2005). The financialization of the American economy. Socio-Economic Review, 3(2), 173-208.

Lascoumes, P., \& Le Galès, P. (2007). Understanding public policy through its instruments: From the nature of instruments to the sociology of public policy instrumentation. Governance: An International Journal of Policy, Administration, and Institutions, 20(1), 1-21.

Marais, H. (2011). South Africa pushed to the limit: The political economy of change. London/New York: Zed.

Martin, S., \& Clapp, J. (2015). Finance for agriculture or agriculture for finance? Journal of Agrarian Change, 15(4), 549-559.

O'Meara, D. (1996). Forty lost years: The apartheid state and the politics of the National Party, 1948-1994. Londres: Ravan Press.

Ortmann, G., \& King, R. (2007). Agricultural cooperatives I: History, theory and problems. Agrekon, 46(1), 18-46.

Ouma, S. (2014). Situating global finance in the land rush debate: A critical review. Geoforum, 57, 162-166.

Senwes (2012). Annual report. Available online at: http://media.senwes.co.za/Global/documents/PDF/Senwes/Reports/ 2012-2013/Interim_Report/Eng/Interim_Report_2012.pdf

Senwes (2013). Annual report. Available online at:: http://media.senwes.co.za/Global/documents/PDF/Senwes/Reports/ 2012-2013/Integrated_Report/Eng/Integrated_Report_2013.pdf

Suidwes. (2013). Integrated annual report. Available online at: http://www.suidwes.co.za/Docs/2013/Annual\%20Report\% 202013.pdf

Van der Zwan, N. (2014). Making sense of financialization. Socio-Economic Review, 12(1), 99-129.

Vink, N. \& Van Rooyen, J. (2009). Perspectives on the performance of agriculture in SA since 1994 and implications for its role in achieving sustainable food policy. Draft Working Paper. Pretoria: University of Pretoria.

Visser, O., Clapp, J., \& Isakson, R. (2015). Introduction to a Symposium on Global Finance and the Agri-food Sector: Risk and Regulation. Journal of Agrarian Change, 15(4), 541-548.

Webb, A. (2000). South African agriculture in the 1970s: A decade of transformation? South African Journal of Economic History, 15(1-2), 159-179.

Williams, J. W. (2014). Feeding finance: A critical account of the shifting relationships between finance, food and farming. Economy and Society, 43(3), 401-431.

Zeder. (2008). Annual report. Available online at: http://www.zeder.co.za/wp-content/uploads/pdf/Zeder_AR_2008.pdf

Zeder. (2009). Annual report. Available online at: http://www.zeder.co.za/wp-content/uploads/pdf/Zeder_Annual\% 20Report_2009_pdf

Zeder. (2010). Annual report. Available online at: http://www.zeder.co.za/wp-content/uploads/pdf/Zeder\%20Annual\% 20Report\%2028 \%20Feb\%202010.pdf

Zeder. (2012). Annual report. Available online at: http://www.zeder.co.za/wp-content/uploads/pdf/Zeder\%2OInvestments\% $202012 \% 20$ Annual\%20report.pdf

How to cite this article: Ducastel A, Anseeuw W. Facing financialization. The divergent mutations of agricultural cooperatives in postapartheid South Africa. J Agrar Change. 2018;1-16. https://doi.org/10.1111/ joac. 12255 